\title{
RANCANG BANGUN MESIN PENCUCI RUMPUT LAUT BERBASIS TEKNOLOGI HYBRID
}

\author{
(PROTOTYPE SEAWEED WASHING MACHINES BASED ON HYBRID \\ TECHNOLOGY)
}

\author{
Williandi Setiawan ${ }^{1,2}$, Indra Jaya ${ }^{3}$, dan Totok Hestirianoto ${ }^{3}$ \\ Bagian Akustik dan Instrumentasi Kelautan \\ Departemen Ilmu dan Teknologi Kelautan-IPB, E-mail: wili_quarte@gmail.com
}

\begin{abstract}
Seaweed has a high economic value in terms of its considerable use in various industries of sweets, cosmetics, ice cream, flavourings, bakery, sauce, silk, meat/fishery canning, medicine and iron-rod welding. In 2005, Indonesia has declared that seaweed as one of the leading commodities to be prioritized and revitalized. To produce quality of industrial-scale seaweed has necessary a serious handling, start from harvesting process, uploading, washing, drying, up to manufacturing caraggenan.This study has tried to produce a seaweed washing machine that capable to improve the quality of the seaweed in the washing process. This washing machine is based on bybrid technology that can be operated using energy from pedal-powered and electrical-powered generated from solar panels.The washing machine resemble three-wheeled transport vehicle using pedal-powered for mobility. Activity of seaweed washing process using plastic drum that rotated. There are two different size of plastic drum used in washing machine, the bigger size for static water storage containers and the little one for dynamic (rotation) using pedal-powered or electrical motor.The rolled chain transmission that connected with integrated toothed gear is used to ratate a dynamic drum. The different between pedal-powered and electrical-motor powered lies in process to rotated dynamic drum. Pedal-powered use manpower to rotated dynamic drum but electrical motor powered from electrical that generated from solar panel. Washing machine with pedal-powered similar like pedal powered that contained in bicycle. Solar panel systems which is the source energy for generated electrical motor consists of solar panel itself, controller, battery and DC to AC converter. Overall the machine has works well butt need improvement in terms of manueverability.
\end{abstract}

Keywords: seaweed, washing machine, pedal-powered, electrical motor-powered, bybrid technology

\begin{abstract}
ABSTRAK
Potensi rumput laut yang sangat besar dan kebutuhan pasar yang amat tinggi, maka perlu adanya pengembangan mesin pengolah rumput laut yang ditujukan untuk meningkatkan nilai tambah yang berlipat ganda dari produk tersebut. Adapun penelitian yang dilakukan adalah sebatas proses pencucian rumput laut dari proses pengolahan secara keseluruhan, dengan membuat rancang bangun mesin pencuci rumput laut berbasis teknologi bybrid, yaitu menggunakan penggabungan sumber energi yang dihasilkan dari sistem pedal dan sistem tenaga matahari. Analisis dilakukan secara deskriptif setelah dilakukan identifikasi terhadap fasilitas dan aktivitas yang ada dan penghitungan kembali kapasitas tempat pelelangan ikan, dermaga dan kolam pelabuhan. Hasil penelitian menunjukkan bahwa berdasarkan tiga belas jenis aktivitas kepelabuhanan perikanan yang tercantum dalam UU RI Nomor 45 Tahun 2009 tentang Perikanan, maka PPI Cituis telah melaksanakannya 9. Permasalahan kurangnya kapasitas dermaga $(154,18 \mathrm{~m})$ dan kedalaman kolam pelabuhan $(70 \mathrm{~cm})$ mengakibatkan terhambatnya aktivitas di PPI Cituis khususnya pendaratan kapal dan pembongkaran hasil tangkapan.
\end{abstract}

Kata-kata kunci: rumput laut, mesin pencuci, tenaga pedal, energi motor elektrik, teknologi hibrid

\section{PENDAHULUAN}

\section{Latar Belakang}

Pada 2005, pemerintah Indonesia telah menetapkan rumput laut sebagai salah satu komoditi unggulan yang diprioritaskan untuk direvitalisasi, dengan alasan: permintaan ekspor masih sangat besar, teknologi budidaya yang mantap dan sangat sederhana, maupun operasional relatif kecil, siklus produksi relatif singkat, hanya sekitar 45 hari, tergolong usaha padat karya, dan areal budidaya tersedia sangat luas.

Selama ini pembudidayaan rumput laut umumnya hanya menjual hasil budidaya dalam bentuk mentah (rumput laut kering) dan belum diolah dengan baik sehingga berkualitas tinggi, sehingga pembudidaya belum mendapatkan nilai

\footnotetext{
${ }^{1}$ Corresponding author

${ }^{2}$ Staf Laboratorium Akustik dan Instrumentasi Kelautan FPIK- IPB

${ }^{3}$ Staf Pengajar Departemen Ilmu dan Teknologi Kelautan FPIK-IPB
} 
kebutuhan modal baik untuk investasi tambah dari hasil rumput laut tersebut.

Menimbang potensi rumput laut yang sangat besar dan kebutuhan pasar yang amat tinggi maka perlu adanya pengembangkan mesin pengolah rumput laut yang ditujukan untuk meningkatkan nilai tambah yang berlipat ganda dari produk tersebut. Adapun penelitian yang akan dilakukan adalah sebatas proses pencucian rumput laut dari proses pengolahan secara keseluruhan, dengan melakukan membuat rancang bangun mesin pencuci rumput laut berbasis teknologi hybrid, yaitu dengan menggunakan penggabungan sumber energi yang dihasilkan dari sistem pedal dan sistem tenaga matahari. Dalam makalah ini diuraikan hasil desain dan konstruksi dari mesin pencuci rumput laut, serta hasil pengujian alat.

\section{BAHAN DAN METODE PENELITIAN}

Kegiatan rancang bangun dilaksanakan selama 8 bulan, dimulai bulan Agustus 2010 sampai dengan Maret 2011, di dua tempat, yaitu : (1) Laboratorium Instrumentasi Kelautan, Departemen ITK, untuk melakukan perancangan mesin pencuci rumput laut dan pengujian lab; (2) Pelabuhan Ratu, Sukabumi, Jawa Barat. sebagai tempat diambilnya sampel rumput laut dari pembudidaya, yakni di Desa Sanggrawayang.

Bahan yang dipakai untuk penelitian adalah sebagai berikut :

(1) Seperangkat Sepeda bekas yang merupakan bagian utama dari sistem mobilitas mesin keseluruhan.

(2) Dua buah drum plastik yang berbeda ukuran sebagai wadah penampung dari rumput laut dan air.

(3) Solar panel merupakan alat untuk mengubah panas matahari menjadi sumber energi listrik.

(4) Kontroler untuk menstabilkan energi listrik yang dihasilkan dari solar panel.

(5) Dc to AC Converter merupakan perangkat yang merubah tegangan DC menjadi tegangan AC.

(6) Baterai kering sebagai media penyimpanan sumber listrik.

(7) Motor AC merupakan motor penggerak yang mengaduk wadah penampungan rumput laut.
(8) Rumput laut jenis Eucheuma Spp. sebagai bahan yang akan diujikan pada mesin

\subsection{Perancangan Konstruksi Mesin Pencuci Rumput Laut \\ Desain mesin pencuci rumput laut} ini menggunakan roda tiga yang dilengkapi dengan pemutar drum plastik dengan ontel. Pada Gambar 1. Terlihat 2 drum plastik yang berbeda ukuran yang digunakan sebagai wadah dalam sistem pencucian. Satu drum yang ukurannya lebih besar bersifat statis yang berfungsi untuk menampung air dengan jumlah maksimum $50 \%$ dari kapasitas drum yang dilengkapi kran outlet air, sedangkan drum yang ukurannya lebih kecil akan ditempatkan didalam drum yang ukurannya lebih besar. Drum tersebut bersifat dinamis yang bergerak memutar yang dihasilkan oleh sistem pedal menggunakan rantai dan gigi roda. Bagian drum dinamis dibuat berlubanglubang dan dipasang palang sejajar sebanyak 4 palang yang memungkinkan terjadinya pengadukan yang merata untuk rumput laut yang dimasukkan ke dalamnya. Tempat memasukkan rumput laut (loading) terdapat pada bagian atas. Rancangan sistem pencuci rumput laut ini dapat dipindahkan dan bersifat mobile, untuk mengantisipasi medan di daerah pesisir budidaya rumput laut dilakukan.

\subsection{Perancangan Sistem Elektronika}

Mesin pencuci rumpun laut teknologi hybrid ini dirancang dengan menggunakan solar panel sebagai sumber energi yang dapat disimpan dalam dry cell battery yang kemudian digunakan untuk menggerakan motor AC. Kemudian, motor AC ini akan memutar wadah (drum) sehingga rumput laut didalam wadah teraduk.

\subsection{Ujicoba Sistem Solar Panel pada Mesin Pencuci Rumput Laut}

Ujicoba ini dilakukan untuk menguji efesiensi dari sistem solar panel dalam beberapa hal, yaitu : perhitungan berapa lama penggunaan baterai untuk menjalankan motor AC, berapa arus yang dibutuhkan untuk menjalankan motor AC terhadap waktu baik dalam keadaan wadah kosong ataupun wadah terisi air dan rumput laut, daya yang dikonsumsi oleh mesin terhadap baterai, serta 
perhitungan putaran drum dinamis (rpm).

\subsection{Uji Coba Mesin Pencuci Rumput Laut}

Uji coba ini dilakukan dengan membandingkan antara kekeruhan air sebelum dilakukan pencucian dan setelah pencucian, dimana alat dioperasikan selama 10 menit kemudian sampel air dikeluarkan dari alat. kontaminan yang terdapat dalam rumput laut akan terlarut dalam air sehingga air berwarna lebih keruh, pengujian dilakukan beberapa kali ulangan dan kemudian diukur menggunakan TDS meter.

\section{HASIL DAN PEMBAHASAN}

\subsection{Bentuk Fisik Rangka Dasar Mesin}

Desain awal dari mesin pencuci rumput laut mengacu pada mesin yang sifatnya fleksibel, ramah lingkungan dan moveable. Mesin dibuat untuk mudah digunakan, praktis, menggunakan energi yang terbarukan serta dirancang untuk dapat berpindah-pindah. Kerangka dasar dari mesin dibuat dari bahan dasar besi yang di sambung dengan sistem pengelasan. Mesin dibentuk menyerupai kendaraan pengangkut beroda tiga, bagian depan yang mempunyai dua roda sejajar diperuntukkan sebagai kerangka pengangkut sedangkan bagian belakang yang merupakan sepeda yang dimodifikasi sebagai kerangka penggerak.

Kerangka untuk penempatan solar panel (Gambar 2.) dipasang terhubung pada bagian kerangka pengangkut. Kemiringan $20^{\circ}$ dari rangka solar panel dibuat agar solar panel dapat menyerap energi matahari optimal pada saat matahari tepat diatas lokasi mesin dioperasikan saja melainkan pada saat posisi matahari baru mulai naik dan hampir tenggelam.

\subsection{Mesin Pencuci dengan Penggerak Sistem Pedal}

Sistem pedal yang digunakan menyerupai sistem pedal pada sepeda, dimana pada sepeda pedal yang dikayuh akan menggerakan roda belakang sehingga dapat berpindah sedangkan pedal pada mesin pencuci ketika dikayuh akan menggerakan atau membuat drum dinamis berputar. Perpindahan gaya yang dihasilkan dari sistem pedal yang dikayuh menuju drum dinamis menggunakan transmisi rantai roll yang berhubungan terpadu dengan roda
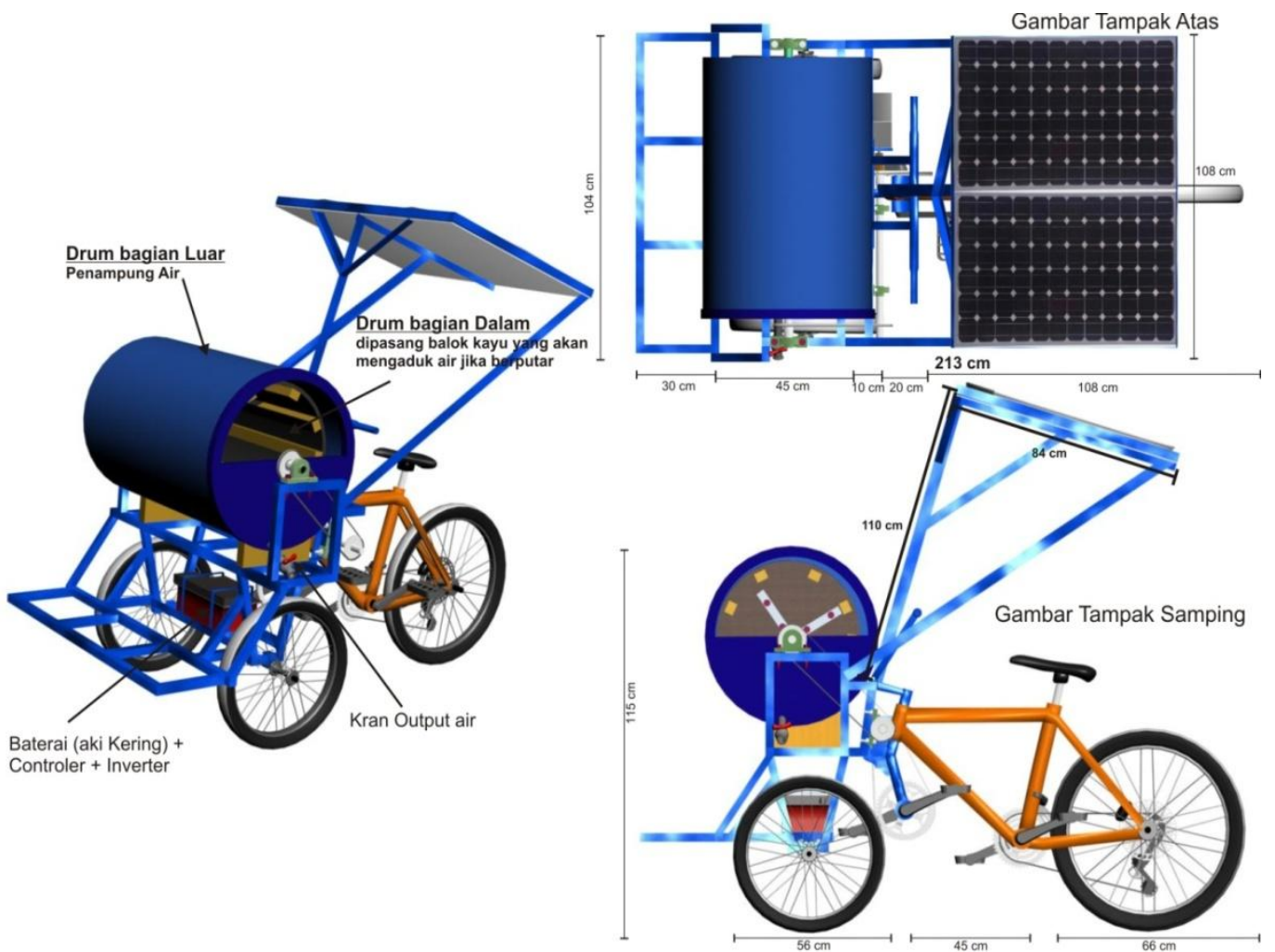

Gambar 1. Desain teknik dari mesin pencuci rumput laut berbasis teknologi hibrid 
bergigi yang disebut sproket (Gambar 2.) Komponen penyusun lainnya adalah penggunaan bearing/bantalan bercangkang yang berfungsi menopang agar batang as dapat berputar pada porosnya dengan stabil. Perbandingan transimisi rantai antara gear gigi pedal dengan spoket mempunyai perbandingan 2 : 1 , yang berarti pada saat gear pedal berputar satu kali pada porosnya sproket akan berputar dua kali. Perbandingan transmisi rantai antara sproket dengan sproket yang posisinya dekat drum dinamis memiliki perbandingan $1: 1$.

\subsection{Mesin Pencuci dengan Penggerak Sistem Motor AC}

Prinsip mekanisme penggerak dengan sistem motor AC hampir sama dengan prinsip mekanisme sistem pedal, yang membedakan adalah untuk sistem pedal sebagai energi penggerak menggunakan tenaga kayuhan yang dilakukan oleh manusia sedangkan untuk sistem penggerak motor AC menggunakan tenaga listrik untuk menggerakkan motor (Gambar 3.). Komposisi komponen alat yang dipakai pada penggerak sistem motor AC ini hampir sama dengan sistem pedal, kecuali adanya tambahan komponen kopling dan motor AC (Gambar 4.).

Motor yang digunakan pada penelitian ini adalah motor AC yang memiliki daya 250 watt, dengan kecepatan putaran kurang lebih 1400 $\mathrm{rpm}$. Motor ini menggunakan gear box sebagai reduksi putaran untuk menaikkan torsi atau kekuatan putar motor. Gear box yang digunakan menggunakan perbandingan gear 1 : 7,5 . Penggunaan kopling bertujuan untuk menghubungkan poros motor dengan poros sistem mekanisme pencucian. Kopling akan memindahkan daya yang dihasilkan oleh motor menuju sistem mekanisme pencucian.

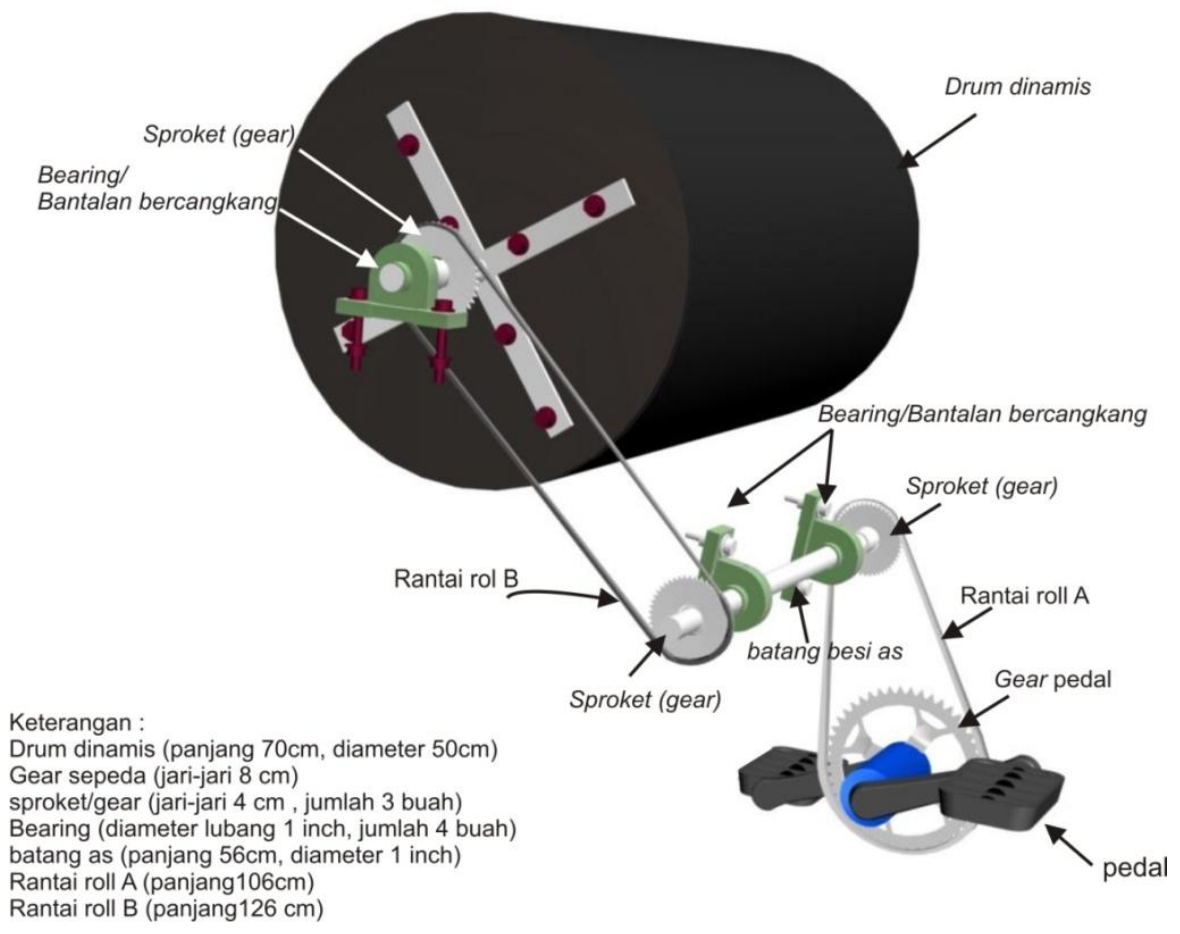

Gambar 2. Mesin pencuci dengan sistem pedal; drum dinamis (panjang $70 \mathrm{~cm}$, diameter $50 \mathrm{~cm})$; gear sepeda $(\mathrm{r}=8 \mathrm{~cm})$, sproket $(\mathrm{r}=4 \mathrm{~cm}$, jumlah 3); bearing (diameter lubang 1 inch, jumlah 4 buah); batang as (panjang $56 \mathrm{~cm}$, diameter 1 inch); rantai roll A (panjang $106 \mathrm{~cm}$ ); rantai roll $\mathrm{B}$ (panjang $126 \mathrm{~cm}$ ) 


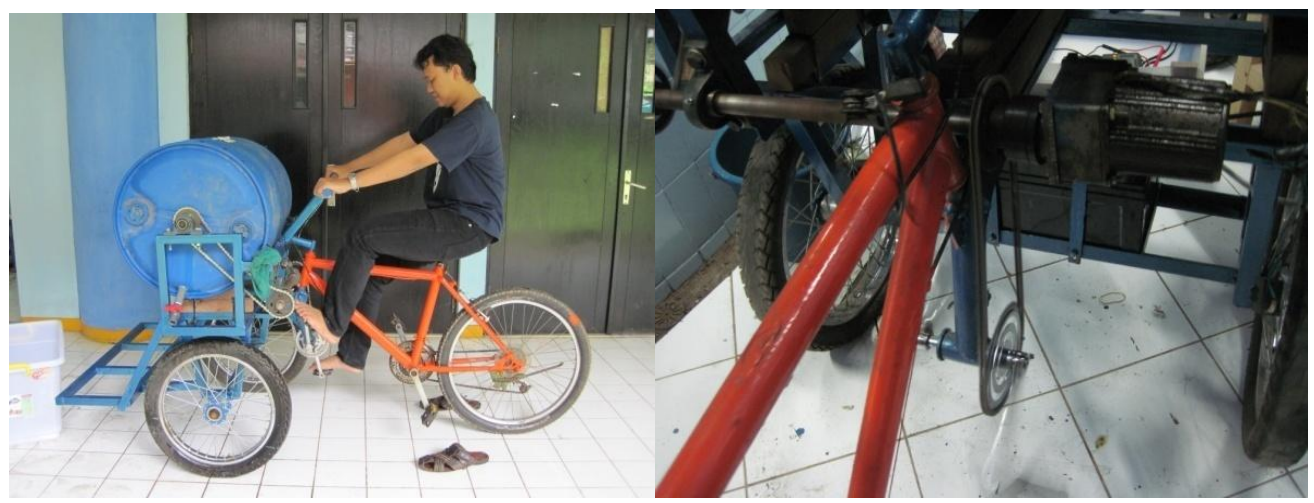

Gambar 3. Mesin pencuci rumput laut (a) dengan sistem pedal; (b) dengan sistem motor

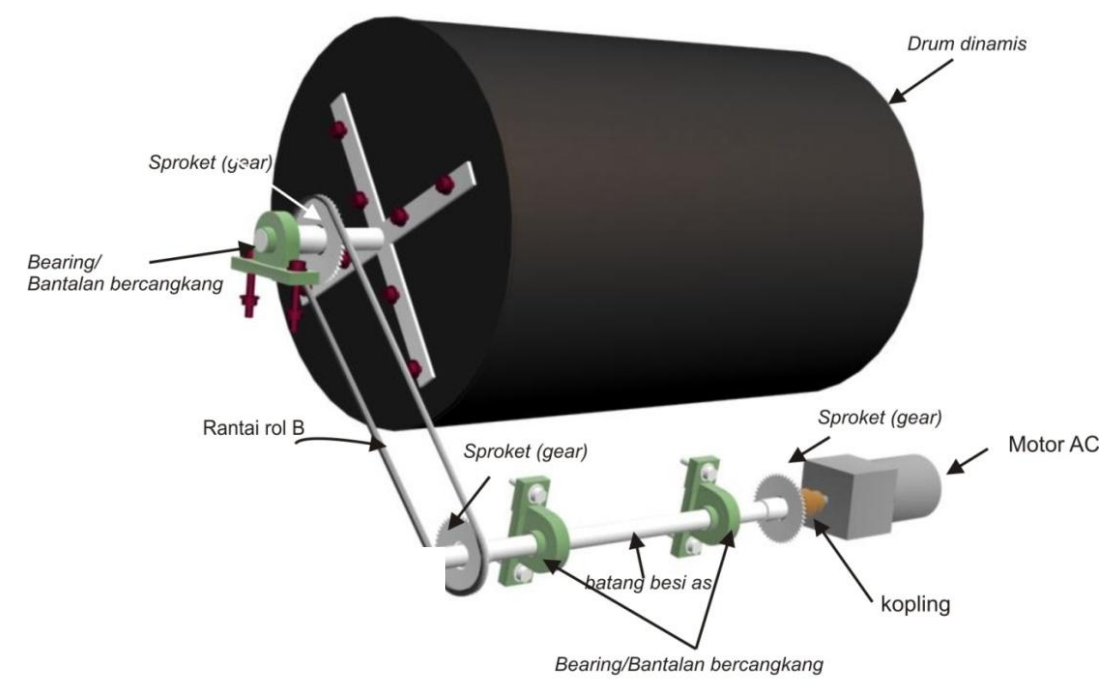

Gambar 4. Mesin pencuci dengan sistem motor AC; drum dinamis (panjang $70 \mathrm{~cm}$, diameter $50 \mathrm{~cm}$ ); sproket $(\mathrm{r}=4 \mathrm{~cm}$, jumlah 3); bearing (diameter lubang 1 inch, jumlah 4 buah); batang as (panjang $56 \mathrm{~cm}$, diameter 1 inch); rantai roll B (panjang $126 \mathrm{~cm}$ ); motor AC (190=220 volt); kopling (diameter lubang $12 \mathrm{~mm}$ to $254 \mathrm{~mm}$ )

\subsection{Mesin Pencuci dengan Penggerak Sistem Hybrid}

Mesin pencuci dengan penggerak sistem hybrid merupakan penggabungan dari kedua sistem penggerak, yaitu sistem pedal dan sistem motor. Penggabungan mekanisme ini dimaksudkan dalam pengoperasian mesin ini dapat saling berbagi. Berbagi disini memiliki arti dapat dioperasikan sendirisendiri maupun dioperasikan secara kooperatif tanpa harus merubah kondisi mekanika mesin. Tabel 1. menjelaskan perbedaan sistem penggerak dalam pengoperasian mesin pencuci secara sendiri-sendiri. Bentuk fisik akhir dari mesin pencuci rumput laut berbasis teknologi hybrid dapat dilihat pada Gambar 5.

\subsection{Hasil Uji Coba \\ 3.5.1.Uji Coba Mobilitas Mesin Pencuci Rumput}

Uji coba dilakukan dengan menjalankan mesin dengan jalur lurus dan jalur memutar. Untuk jalan dengan jalur lurus tidak mengalami hambatan. Hambatan yang dialami yaitu pada saat kondisi berbelok, hal ini dikarenakan posisi sumbu kendali (stang) yang berada di bagian atas menyebabkan pada saat berbelok posisi sepeda yang ditunggangi tidak tegak lurus (miring) pada sumbu normal sehingga untuk mengendalikannnya pengguna harus memutar badannya ke arah mesin berbelok. 
Tabel 1. Perbedaan pemakaian sistem penggerak dalam pengoperasian mesin pencuci rumput laut

\begin{tabular}{|l|l|l|}
\hline & \multicolumn{1}{|c|}{ Sistem Pedal } & \multicolumn{1}{c|}{ Sistem Motor } \\
\hline $\begin{array}{l}\text { 1. Bobot dan } \\
\text { volume air }\end{array}$ & $\begin{array}{l}\text { Bobot rumput laut 10 -15 } \\
\text { kg, volume air maksimal } \\
110 \text { liter }\end{array}$ & $\begin{array}{l}\text { Bobot rumput laut maksimal 5 kg } \\
\text { dan volume air maksimal 36 liter }\end{array}$ \\
\hline $\begin{array}{l}\text { 2. Perputaran } \\
\text { drum dinamis } \\
\text { pada porosnya }\end{array}$ & $\begin{array}{l}\text { Tidak menentu, tergantung } \\
\text { kekuatan otot kaki } \\
\text { pengguna }\end{array}$ & Perputaran Konstan \\
\hline $\begin{array}{l}\text { 3. Lama } \\
\text { pengoperasian }\end{array}$ & $\begin{array}{l}\text { Tidak menentu, tergantung } \\
\text { kekuatan otot kaki } \\
\text { pengguna }\end{array}$ & $\begin{array}{l}\text { Dengan perlakuan diberikan } \\
\text { bobot kurang lebih 4 jam }\end{array}$ \\
\hline 4. Bentuk energi & $\begin{array}{l}\text { Ramah lingkungan, } \\
\text { menggunakan kekuatan } \\
\text { otot manusia }\end{array}$ & $\begin{array}{l}\text { Ramah lingkungan menggunakan } \\
\text { energi terbarukan, yaitu } \\
\text { menggunakan solar panel }\end{array}$ \\
\hline
\end{tabular}

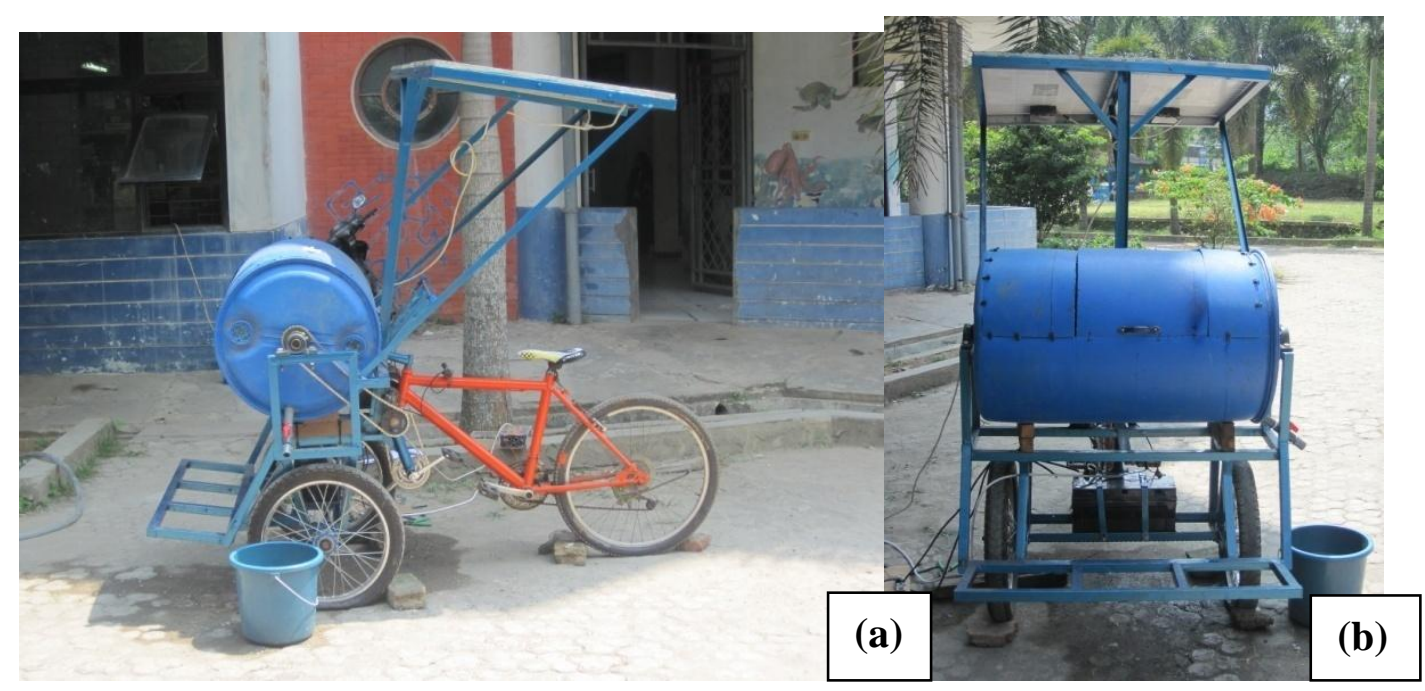

Gambar 5. Bentuk akhir mesin pencuci rumput laut berbasis teknologi hybrid (a) tampak samping; (b) tampak depan

\subsubsection{Uji Coba Sistem Penggerak Pencuci Rumput Laut dengan Sistem Motor AC}

Untuk mengetahui daya yang dikonsumsi oleh mesin dilakukan pengukuran pada baterai. Pengukuran dilakukan untuk mendapatkan nilai tegangan dan arus yang mengalir sebelum akhirnya masuk konverter DC to AC. Pengukuran dilakukan dengan mengunakan Digital multimeter untuk mengukur tegangan dan Ampermeter DC untuk mengukur arus sehingga kita dapat mengukur daya yang dikeluarkan.

Pengukuran daya (watt) dilakukan dengan 2 perlakuan, yaitu drum dinamis berputar dengan diberi beban (volume air 36 liter) dan tanpa diberi beban. Pengukuran tegangan dan arus dilakukan tiap 10 menit dari menit pertama sampai dengan kondisi baterai tidak dapat membuat motor berputar lagi (baterai habis).

\subsubsection{Perlakuan pengukuran dengan beban}

Pengukuran daya konsumsi motor dengan menggunakan beban untuk membuat motor AC berputar (Gambar 6.) pada detik pertama dibutuhkan konsumsi daya sebesar 896 watt kemudian beberapa detik kemudian konsumsi daya menurun drastis sampai dengan 619 watt pada menit pertama. Hal ini disebabkan karena pada awalan, motor akan menyerap arus lebih besar dari kondisi stabilnya. Arus awal yang diserap dari baterai adalah 70 ampere sedangkan pada saat stabil/konstan adalah 50 ampere. Daya minimum yang di konsumsi baterai adalah 586 watt. Waktu yang dibutuhkan untuk baterai 
pada perlakuan dengan beban hingga motor tidak dapat bekerja lagi adalah 240 menit atau 4 jam operasi.

Kecepatan putar drum dinamis adalah $18 \mathrm{rpm}$. Tegangan pada motor sebesar 210 volt dan arus yang dihasilkan sebesar 0.9 ampere sehingga dihasilkan daya pada motor sebesar 189 watt sehingga didapatkan torsi dari motor adalah 10,5 Nm.

\subsubsection{Perlakuan pengukuran tanpa beban}

Pengukuran daya konsumsi motor dengan tanpa beban untuk membuat motor AC berputar (Gambar 6.)pada detik pertama dibutuhkan konsumsi daya sebesar 793,2 watt kemudian beberapa detik kemudian konsumsi daya menurun drastis sampai dengan 376,8 watt pada menit pertama. Seperti halnya pada kondisi dengan beban, pada awalan, motor akan menyerap arus dua kali lipat dari kondisi stabilnya. Arus awal yang diserap dari baterai adalah 60 ampere sedangkan pada saat stabil/konstan adalah 30 ampere. Daya minimum yang di konsumsi baterai adalah 346,5 watt. Waktu yang dibutuhkan untuk baterai pada perlakuan dengan beban hingga motor tidak dapat bekerja lagi adalah 480 menit atau 8 jam operasi.

Kecepatan putar drum dinamis adalah 92 rpm. Tegangan pada motor sebesar 190 volt dan arus yang dihasilkan sebesar 0,9 ampere sehingga dihasilkan daya pada motor sebesar 171 watt sehingga didapatkan Torsi dari motor adalah 1,86 $\mathrm{Nm}$.

Jika dibandingkan, daya yang dikonsumsi oleh baterai untuk menggerakkan motor ac dengan adanya beban akan lebih banyak mengkonsumsi daya lebih banyak dibandingkan dengan perlakuan tanpa beban (Gambar 6.).
Kecepatan putar untuk drum dinamis menggunakan beban lebih sedikit dibandingkan dengan tanpa menggunakan beban, yaitu $18 \mathrm{rpm}$ untuk perlakuan menggunakan beban dan 92 rpm untuk perlakuan tanpa beban. Torsi dari motor ac untuk perlakuan menggunakan beban 10,5 Nm sedangkan tanpa perlakuan beban, yaitu $1,86 \mathrm{Nm}$.

\subsubsection{Uji Coba Pencucian Rumput Laut}

Uji coba ini dilakukan dengan membandingkan antara kekeruhan air sebelum dilakukan pencucian dan setelah pencucian, dimana alat dioperasikan selama 10 menit kemudian sampel air dikeluarkan melalui outlet drum statis. Sampel rumput laut yang dipakai adalah jenis Eucheuma Spp. Kontaminan yang terdapat dalam rumput laut akan terlarut dalam air sehingga air menjadi berwarna lebih keruh. Pengujian dilakukan dengan mengukur jumlah partikel organik dan anorganik yang terkandung dalam air sampel dengan menggunakan TDS(Total Dissolved Solids) meter. Ada tiga sampel air yang diukur adalah (1) air sebelum pencucian (kontrol); (2) air sampel pencucian ulangan pertama; (3) air sampel pencucian ulangan kedua.

Hasil pengukuran dilakukan sebanyak 3 kali ulangan yang kemudian hasilnya dirata-ratakan. Gambar 7 . merupakan grafik hasil pengukuran sampel air dengan menggunakan TDS meter. Grafik tersebut menunjukan untuk sampel air kontrol banyaknya jumlah rata-rata partikel organik dan anorganik pada air sampel adalah 126,3 $\mathrm{mg} / \mathrm{L}$ sedangkan untuk sampel ulangan ke satu dan ke dua secara berturut-turut adalah 1838,0 mg/L dan 1049,3 mg/L. 


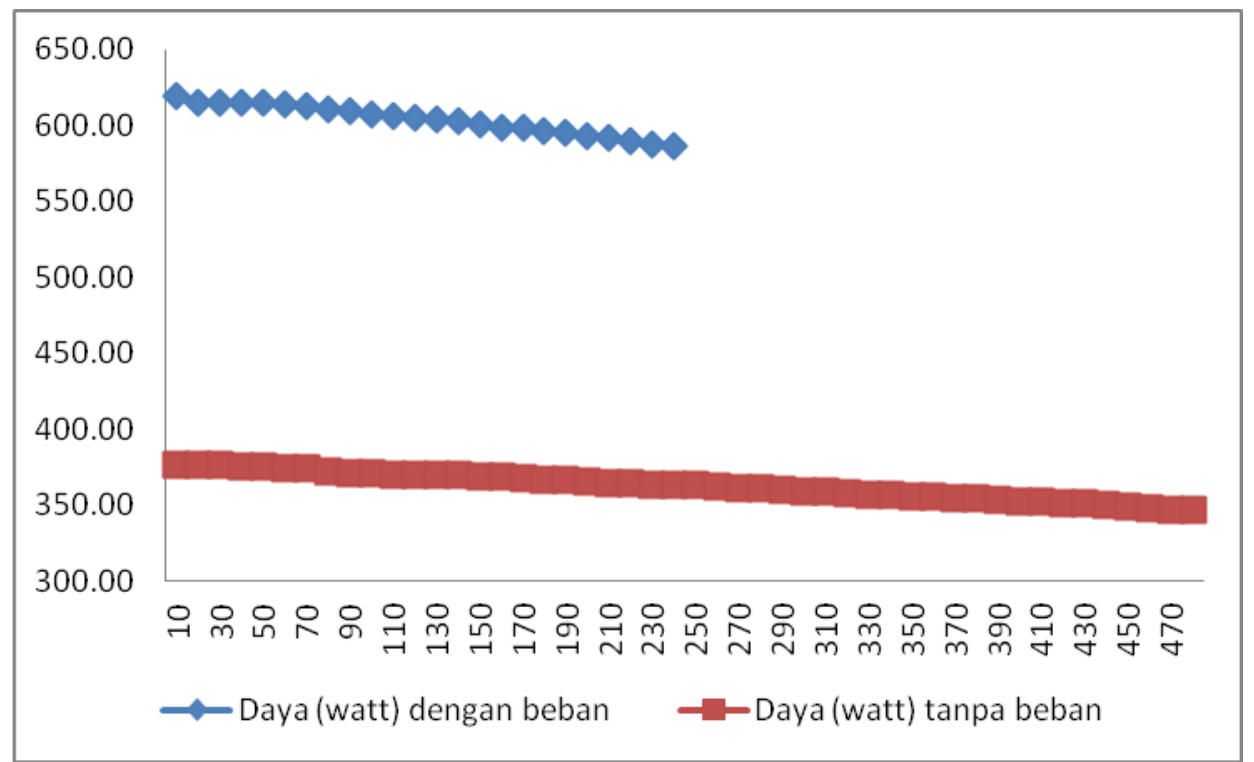

Gambar 6. Perbandingan daya yang diperlukan untuk menggerakkan motor AC antara perlakukan dengan beban dan tanpa beban

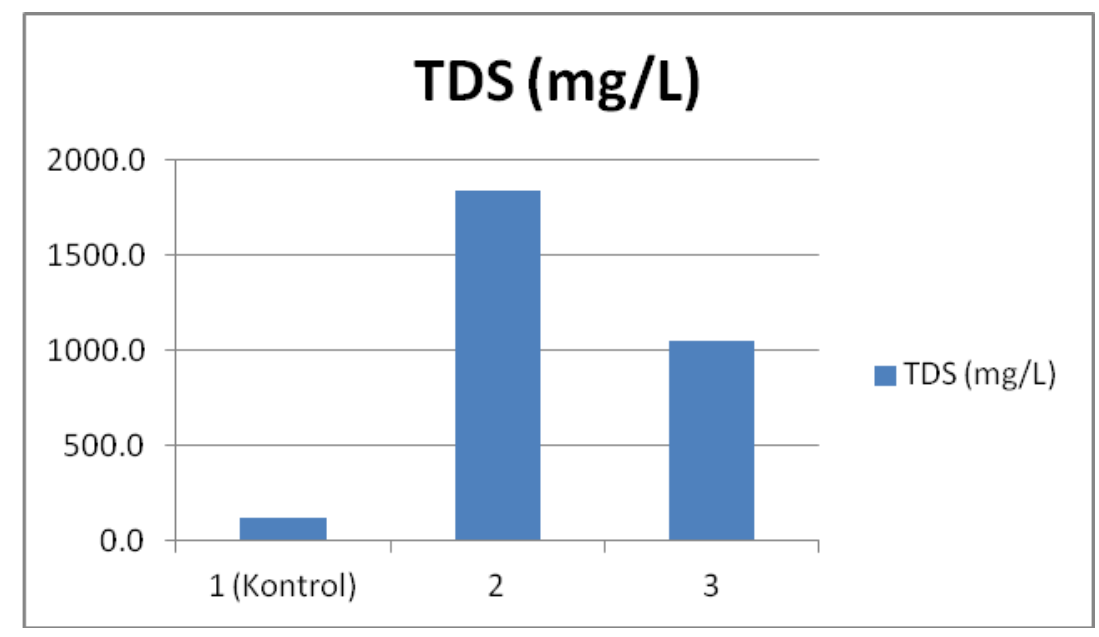

Gambar 7. Diagram batang hasil pengukuran TDS air sampel

\section{KESIMPULAN DAN SARAN}

\subsection{Kesimpulan}

Komponen mekanis dari mesin pencuci rumput laut ini menggunakan transmisi rantai roll yang terhubung antara dua sproket (roda bergigi), dengan bantuan bearing/bantalan bercangkang dan kopling untuk menopang dan menghubungkan poros yang mencengram drum dinamis. Sistem pencuci dengan sistem pedal menggunakan tenaga manusia untuk pengoperasiannya sedangkan untuk sistem motor AC menggunakan energi listrik yang didihasilkan dari sistem solar panel.
Hasil uji coba sistem motor AC pada mesin pencuci rumput laut dilakukan dengan dua perlakuan, yaitu perlakuan dengan menambahkan beban dan tanpa menambahkan beban. Perlakuan menggunakan beban memiliki daya konsumsi baterai lebih banyak dari konsumsi baterai tanpa beban pada pengoperasian mesin pencuci rumput laut dengan sistem motor.

\subsection{Saran}

Desain dan rancang bangun mesin yang telah dihasilkan diharapkan ada pengembangan secara berlanjut sehingga mampu mengatasi kelemahan dan kekurangan dari produk sebelumnya, 
seperti mobilitas dari mesin yang sulit dikendalikan pada jalur berputar, kekuatan torsi perlu ditingkatkan baik dengan meningkatkan torsi motor atau penggunaan perbandingan gigi bergigi/sproket yang lebih besar sehingga dapat beroperasi dengan beban yang lebih banyak.

Perlu pengujian berlanjut untuk mengetahui kegunaan lain dari mesin ini, yaitu apakah dapat digunakan sebagai pengering rumput laut seperti prinsip pengering baju pada mesin cuci

\section{DAFTAR PUSTAKA}

Goodwin, G.C. 2000. Control system design. Prentice Hall.

Hu, J., Radu R., Jessica V. 2005. The Pedal-Powered Washing Machine. Final

Report.http//www.web.mit.edu/ter esab/www/Bicilavadora/index.htm l, Agustus 2010.
Kularatna, N. 2003. Digital and Analogue Mesintation testing and measurement. The Institution of Engineering and Technology, London, United Kingdom.

Miller, John M. 2004. Propulsion System for Hybrid Vehicle. Institution of Engineering and Technology. London United Kingdom.

Mott, Robert L. 2004. Elemen-elemen Mesin dalam Perencanaan Mekanis. Penerbit Andi Yogyakarta.

Nur Hira W., Julian Eka W. 2006. Perkembangan Komoditi Rumput Laut Indonesia. PT. Bank Ekspor Indonesia (Persero).

Patel, Mukund R. 2000. Wind and Solar Power System. CRC Press London New York Washington DC. 
